\title{
Risk perception in subjects at-risk for Familial Amyloidotic Polyneuropathy*
}

\section{Percepción del riesgo en sujetos con riesgo de Polineuropatía} Amiloide Familiar

Received: 13 October 2015 | Accepted: 15 February 2017

\author{
ÂNGELA Leite ${ }^{\mathrm{a}}$ \\ European University of Lisbon, Portugal \\ ORCID: http://orcid.org/0000-0003-0560-1756 \\ Maria Alzira Pimenta Dinis \\ UFP Energy, Environment and Health Research Unit \\ (FP-ENAS), Portugal \\ Jorge SEQueIros \\ Institute for Molecular and Cell Biology, Portugal \\ Constança Paúl \\ Instituto de Ciências Biomédicas Salazar (ICBAS),
}

Portugal

a Correspondance author. E-mail: angelamtleite@gmail.com

How to cite: Leite, Â., Dinis, M. A.. P., Sequeiros, J., Paúl, C. (2017). Risk perception in subjects at-risk for Familial Amyloidotic Polyneuropathy. Universitas Psychologica, 16(3), 1-9. https://doi.org/10.11144/Javeriana.upsy16-3.rpsf

\begin{abstract}
The aims of this study are to know if subjects at-risk were aware of their 50\% risk for Familial Amyloidotic Polyneuropathy (FAP); to know the value of the subjective risk; to understand the association between sociodemographic characteristics and risk perception, and between the risk status and the subjective perception of risk. 174 subjects $50 \%$ atrisk for FAP were tested. 52.9\% subjects at-risk were aware of their 50\% risk condition. The mean value of the subjective risk was higher and closer to $50 \%$ when the subjects were aware of their 50\% risk condition. Education was associated to a higher awareness of being at 50\% risk. It seems that information on previous knowledge before performing the genetic counselling increases the subjective risk.

\section{Keywords}

Risk perception; psychological risk; subjective risk; objective risk; familial amyloidotic polyneuropathy (FAP)
\end{abstract}

\section{RESUMEN}

Los objetivos de este estudio son saber si los sujetos en riesgo eran conscientes de su riesgo del 50\% para la polineuropatía amiloide familiar (PAF); conocer el valor del riesgo subjetivo; y comprender la asociación entre las características sociodemográficas y la percepción del riesgo y entre el riesgo real y la percepción subjetiva del riesgo. Se examinaron 174 sujetos con riesgo de PAF del 50\%. 52,9\% de los sujetos en riesgo eran conscientes de su condición de riesgo del 50\%. El valor medio del riesgo subjetivo fue mayor y más cercano al 50\% cuando los sujetos eran conscientes de su condición de riesgo del 50\%. La educación se asoció a una mayor conciencia de estar al 50\% de riesgo. Parece que la información sobre los conocimientos previos antes de realizar el asesoramiento genético aumenta el riesgo subjetivo.

Palabras clave 
Ângela Leite, Maria Alzira Pimenta Dinis, Jorge Sequeiros, Et al.

Percepción del riesgo; riesgo psicológico; riesgo subjetivo; riesgo objetivo; polineuropatía amiloide familiar (PAF)

\section{Introduction}

Risk perception is understood as the ability of a subject to discern a certain amount of risk, while risk tolerance refers to a person's capacity to accept a certain amount of risk (Inouye, 2014). Accordingly, the risk that exists independently of a subject's knowledge and worries of the source of the risk is known as objective risk (Ulleberg \& Rundmo, 1996). Thus, the perceived risk, or subjective risk, is a reflection of the real risk, especially when risks are well-known (Sjöberg, Moen, \& Rundmo, 2004). In other words, humans perceive and act on risk in two ways: risk as feelings refers to subjects' instinctive and intuitive reactions to danger; risk as analysis refers to logic, reason, and scientific deliberation to take into account on risk management. Reliance on risk as feelings is described as "the affect heuristic" (Slovic \& Peters, 2006). However, Slovic and Elke (2002) stated that risk does not exist "out there", independently of people's minds and cultures, waiting to be measured. Instead, it is seen as a concept that helps to understand and cope with the dangers and uncertainties of life. Darker and Phillips (2016) stated that there are three dimensions of perceived risk: perceived likelihood, i.e. the probability that one will be harmed by the hazard; perceived susceptibility, i.e. an individual's constitutional vulnerability to a hazard; and perceived severity, i.e. the extent of harm a hazard would cause. It is clear that the level of perceived risk of a new technology or product may be considered an important early indicator of the public's alertness to its potential hazards (Sjöberg, 2004).

Risk perception has become increasingly important in the last years, receiving particular attention for its influence on the attitudes and decisions of subjects and social groups regarding the acceptance of various modern technologies and activities, such as nuclear energy and gene technology (Al-Rawad \& Al Khattab, 2015). A culturally sensitive mid-range theory of risk perception, recently proposed by Siaki, Loescher and Trego (2013), suggests that risk appraisals are influenced by affect, health-world views, cultural customs, and protocols that intersect with the health risk. On the other hand, trust in the science behind risk assessments and risk management is possibly more important than social trust, although both types of trust should be considered (Sjöberg, 2012).

As a consequence of the growth of knowledge and of an increasing number of genetic tests, genetic counseling can be offered to more and more subjects, couples and families (EversKiebooms \& Decruyenaere, 1998). Predictive DNA-tests may provide information about the "future health status" of an asymptomatic person (Evers-Kiebooms, Welkenhuysen, Claes, Decruyenaere, \& Denayer, 2000). The "not-yetill" is a rather peculiar expression used to describe a new social category of subjects (Jamieson, 2001). Understanding how people adapt to and manage inherited risk would be useful in the planning and provision of genetics health services (Etchegary, 2011).

Familial Amyloidotic Polyneuropathy (FAP) is a progressive neurodegenerative disease, inherited as an autosomal dominant trait (Coutinho, 1976). It is a late onset disease with no cure, although there are already two types of treatment, liver transplantation and a new drug, Tafamidis (Coelho et al., 2012). However, these two different therapeutic approaches do not heal the patients. Instead, they just prevent the disease progression and delay its development.

A protocol of genetic counselling and psychosocial evaluation and support, before and after pre-symptomatic testing (PST), is thought to be important to a healthy adjustment to the test results (Sequeiros, 1996). The multidisciplinary approach to predictive testing for the Huntington Disease (HD) has been used as a model for predictive testing for other late onset neurodegenerative diseases (EversKiebooms \& Fryns, 1999). According to Quaid et al. (2008), people at-risk for HD bear a greater burden regarding concealment and disclosure than do people at risk for other chronic or lifethreatening conditions. The choice of performing 
the predictive testing should be a well-informed, free, and personal decision of the test applicant without external pressure (Evers-Kiebooms et al., 2000).

According to Brewer et al. (2007), risk perception is central to most health-specific behavioural theories. Thus, all the health professionals working with families who may apply for or are already involved in predictive testing, should be aware of the psychological meaning of genetic risk and genetic test results (Evers-Kiebooms et al., 2000). People's emotional reactions to risk often depend on the vividness with which negative consequences can be imagined or experienced (Weber, 2006). Indeed, and according to Joffe (2003), the way in which people approach and evaluate risks is influenced by other people. That is why risk perceptions are probably more important when people make individual decisions about a behavior with relatively diffuse external influences (Brewer et al., 2007). Disagreements about risk should not be expected to disappear in the presence of evidence. According to Slovic (1987), strong initial views before performing predictive testing are resistant to change because they are able to influence the way subsequent information is interpreted. Accordingly, there are many interwoven social, biographical, and temporal factors which shape and differentiate the relevance of hereditary risk (Cox \& McKellin, 1999).

It is extremely important to realise what is the psychological meaning of being at 50\% risk for FAP. This risk influences the entire life of the subject at-risk for this specific disease. Although the risk to develop the disease decreases gradually with age, at-risk subjects for FAP are never entirely sure that they have escaped the disease. In fact, the variable age of onset is an additional source of uncertainty (Evers-Kiebooms et al., 2000) and each son or daughter of an affected person has a 50\% chance of developing any of these diseases and is often referred to as "being at-risk", a state described as living with an abiding sense of impending threat, according to Taylor (2003) and Wexler (1979). Moreover, the additional psychological risk should not be underestimated (Folstein, Franz, Jensen, Chase, \& Folstein, 1983), although a subject prediction about the exact age of onset, the specific symptoms of the disease or its evolution is impossible. This means that a degree of uncertainty will always persist (Evers-Kiebooms \& Decruyenaere, 1998). Some untested subjects at-risk are aware of their $50 \%$ risk, and some are not. However, both groups evaluate the subjective risk in a different way. According to Cantor and Norem (1989), overestimation and underestimation of the risk has occurred in untested persons, although the majority of the subjects usually overestimates the benefits and underestimates the harm of treatments, screening, and tests (Hoffmann \& Del Mar, 2015).

\section{The present study}

The aims of the study are mainly four (i) to estimate how many subjects at-risk are aware of their 50\% risk condition; (ii) to estimate the subjective risk of subjects at-risk; (iii) to verify if there is any association between the sociodemographic characteristics of the subjects and their risk perception; and (iv) to clarify the association between the risk status and the subjective perception of risk.

The considered hypothesis are two: (i) subjects at-risk who perform the PST, already aware of their 50\% risk condition, will estimate their risk closer to $50 \%$ than the subjects at-risk who are not aware of their risk status, and (ii) subjects at-risk who undergo the PST, aware of their $50 \%$ risk, will estimate their risk lower than the subjects at-risk who are not aware of their risk status.

\section{Methods}

\section{Participants}

174 subjects at-risk, presenting a genetic risk of $50 \%$ for FAP, were studied. Subjects at-risk with a genetic risk of $50 \%$ are the subjects 
Ângela Leite, Maria Alzira Pimenta Dinis, Jorge Sequeiros, Et al.

who descend from a progenitor, or had at least one brother with a molecular diagnosis of carrier. These subjects were asymptomatic, aged equal or older than 18 years and they had not been yet tested for the disease. The definition of 18 years as the minimum age to participate in this study is related with ethical and legal problems arising when persons ask for genetic testing for persons younger than 18 years. Exceptionally, young people aged 17 are accepted if they become 18 during the genetic counselling process. All the subjects at-risk were registered in the genetic counselling programme of the Center for Predictive and Preventive Genetics (CGPP), in order to know their genetic status, and have accepted to participate in the present study.

The studied sample included 104 (60\%) women and 70 (40\%) men. The age ranged between 17 and 66 years, with a mean age of $27.40(\mathrm{SD}=10.38) .165(95 \%)$ subjects atrisk have Portuguese nationality and the rest have foreign nationality. Of the total sample, one subject (1\%) is illiterate, $76(47 \%)$ subjects have basic education, 44 (25\%) subjects have the $9^{\text {th }}$ grade, $41(24 \%)$ subjects have the $12^{\text {th }}$ grade, and $12(7 \%)$ subjects have a university education.

\section{Design and procedure}

The study was based on a protocol designed and conceived by the authors to study the awareness, knowledge, and attitudes of Portuguese people concerning the genetic testing for inherited progressive neurodegenerative late onset diseases. All individuals have attended consultations for genetic counselling in the Center for Preventive and Predictive Genetics, Institute for Molecular and Cell Biology, in order to know their genetic risk for the disease or to know the risk to transmit the disease. This study's protocol is applied immediately before the first counselling protocol session. One of the protocol's issues concerns risk perception. The subjective perception of this risk was assessed with a closed question and a task: subjects at-risk were encouraged to choose between two options - whether they were aware or not of their risk condition and then they had to estimate their subjective risk by marking a cross in a line that starts begging with a 0\% risk and ends at a 100\% risk, with major tick marks every 10\% (Table 1). All subjects have been explained the specific nature of the research, the objectives of the study and the type of treatment to be given to the data. The confidentiality of the data was made clear. The informed consent to voluntary collaborate in the research was also obtained.

\section{TABLE 1}

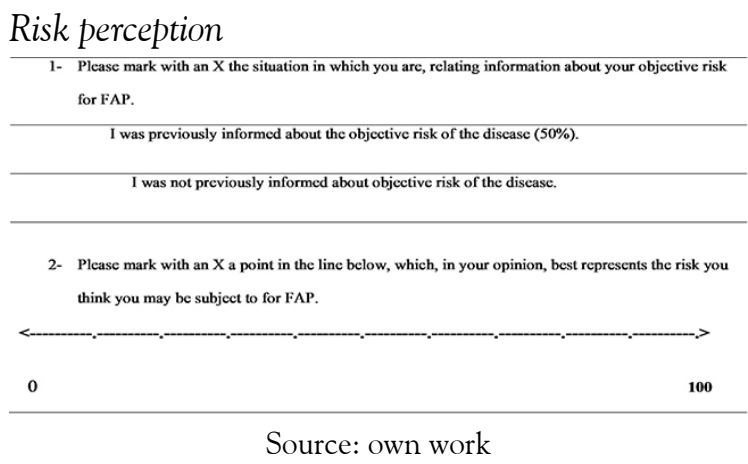

\section{Results}

From a total number of 174 (100\%) subjects at-risk for FAP, 159 (91\%) answered whether they were or not informed about their risk, until the moment they were being questioned about it. The remaining 15 (9\%) subjects at-risk did not understand the question and, for that reason, their answer was not taken into account. Among the 159 subjects that answered about their awareness of the risk, 92 (53\%) were aware of their 50\% condition of genetic risk, and 67 (39\%) were not.

The value of the subjective risk is higher (51\%) and closer to $50 \%$ when the subjects are aware of their 50\% risk condition, than when they were not $(45 \%)$. There are significant statistical differences regarding the subjective risk, between the subjects that were aware of their 50\% risk condition and those who were not $[F(1.157)=$ 4.143, $p<0.050)$ ].

Analyzing Table 2, it is possible to observe that subjects who were aware of their 50\% risk condition had more education than the subjects who were not aware. Gender, age, and 
nationality did not influence the choice of the risk perception's value.

TABLE 2

Characterization of the sample regarding risk awareness $(n=159)$

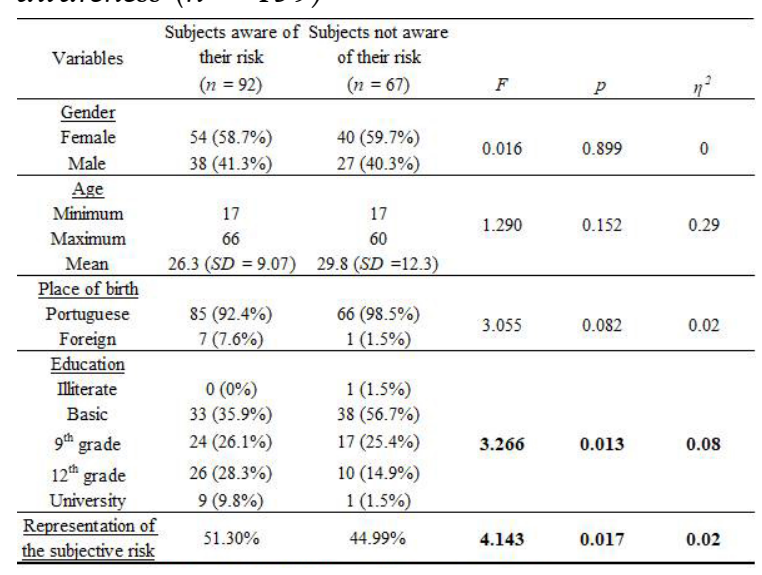

$n$ sample size; F Snedcor's F-

distribution; $p$ p-value; ${ }_{\eta}^{2}=$ eta squared

Source: own work.

The difference between the subjective value of the risk for FAP cannot be considered statistically significant regarding gender, nationality, and education (women, foreign citizen, and more educated people present the highest values). On the contrary, significantly different values are found regarding age, since older subjects tend to choose a higher value of subjective risk (Table 3 ).
TABLE 3

Characterization of the sample according to the value of subjective risk $(n=174)$

\begin{tabular}{|c|c|c|c|c|c|}
\hline Variables & $\begin{array}{c}\text { Sample } \\
(n=174)\end{array}$ & $\begin{array}{c}\text { Subjective } \\
\text { risk }\end{array}$ & $F$ & $p$ & $\eta^{2}$ \\
\hline \multicolumn{6}{|l|}{ Gender } \\
\hline$\overline{\text { Female }}$ & $104(59.8 \%)$ & 49.97 & \multirow{2}{*}{0.437} & \multirow{2}{*}{0.509} & \multirow{2}{*}{0.01} \\
\hline Male & $70(40.2 \%)$ & 47.34 & & & \\
\hline \multicolumn{6}{|l|}{ Age } \\
\hline Minimum & 17 & Range & \multirow{3}{*}{1.529} & \multirow{3}{*}{0.041} & \multirow{3}{*}{0.30} \\
\hline Maximum & 66 & 0 & & & \\
\hline Mean & $27.4(S D=10.38)$ & 80 & & & \\
\hline \multicolumn{6}{|l|}{ Place of birth } \\
\hline Portuguese & $165(94.8 \%)$ & 48.07 & \multirow[t]{2}{*}{3.524} & \multirow[t]{2}{*}{0.062} & \multirow[t]{2}{*}{0.02} \\
\hline Foreign & $9(5.2 \%)$ & 64.44 & & & \\
\hline \multicolumn{6}{|l|}{ Education } \\
\hline Illiterate & $1(0.6 \%)$ & 50 & \multirow{5}{*}{0.168} & \multirow{5}{*}{0.954} & \multirow{5}{*}{0.01} \\
\hline Basic & $76(43.7 \%)$ & 47.22 & & & \\
\hline $9^{\text {th }}$ grade & $44(25.3 \%)$ & 50.77 & & & \\
\hline $12^{\text {th }}$ grade & $41(23.6 \%)$ & 49.29 & & & \\
\hline University & $12(6.9 \%)$ & 51.42 & & & \\
\hline
\end{tabular}

\section{Discussion}

The first hypothesis, based on the idea that subjects at-risk, who perform the PST aware of their 50\% risk condition, will estimate their risk closer to $50 \%$ than the subjects at-risk who are not aware of their risk status, has been confirmed. In fact, the subjective risk is closer to $50 \%$ (52\%) when the subjects are aware of their $50 \%$ risk than when they are not (45\%) and the difference is significant. It means that the knowledge of the real risk condition (50\%) influences the subjective perception of the risk when compared with the risk perception of those subjects who did not know their real risk condition previously to performing the PST: the knowledge of the objective risk takes subjects to perceive risk closer to the value of the objective risk. This may happen because previous knowledge is usually supported by trained professionals. And, although the communication of the risk may have been misunderstood by the subjects at-risk -because it was not properly contextualized or explained, which can lead to overestimation or underestimation of the risk, according to Cantor and Norem (1989)- the subjects previously informed about the objective risk tend to retain the value and evoke it when asked about it. 
Ângela Leite, Maria Alzira Pimenta Dinis, Jorge Sequeiros, Et al.

The second hypothesis, based on the idea that subjects at-risk who perform the PST aware of their 50\% risk condition will estimate a lower risk than the subjects at-risk who are not aware of their risk status, has not been proved. On the contrary, the subjects at-risk conscious of their $50 \%$ objective risk estimated a higher risk value than those who were not aware of the objective risk value. Hoffmann and Del Mar (2015) may help to explain why that happens, when they state that the majority of the subjects usually overestimates the benefits and underestimates the harm of treatments, screening, and tests.

Subjects who were aware of their 50\% risk condition had more education than the subjects who were not aware. More educated subjects have a significant amount of previous information regarding the objective risk than those with less education. This is in agreement with the statements of Siaki et al. (2013), who suggest that risk appraisals are influenced by affect, health-world views, cultural customs, and protocols that intersect with the health risk. The fact that more educated subjects are more informed than the less educated ones may suggest that education can act as a filter of media information, since one of the effects of the media attention, that has undoubtedly accompanied genetics advances, is the increasing anxiety among a wider range of subjects atrisk (Patenaude, Guttmacher, \& Collins, 2002). According to Petersen (2001), anxiety about genetic health risks may occur even in people for whom genetic testing or treatment is not yet an option. This anxiety may be due in part to misconceptions about current genetic knowledge, fuelled by some overly optimistic press reports. Given the vast amount of genetic information available on the scientific literature and on the internet in general, it has been postulated the usefulness for mental health professionals to be able to help patients seeking further knowledge from legitimate resources (Patenaude et al., 2002).

Older subjects tend to choose a higher value of subjective risk than younger ones. Perhaps it might be stated that older people have less risk tolerance, when considering what Inouye
(2014) claims, when defining risk tolerance as the person's capacity to accept a certain amount of risk. Working through worst-case scenarios provides an element of control for the subjects. They prepare themselves for the worst, which may consist in a bad test result, the onset of the disease, and then try to come to terms with it (Lippman-Hand \& Fraser, 1979). That may also be explained by keeping in mind that overestimation of the risk occurs more than underestimation, and this may also suggest that some persons at-risk adopt a defensive pessimism strategy, which involves setting unrealistic low expectations in a risky situation and working through worst-case situations in an attempt to control anxiety (Cantor \& Norem, 1989).

In conclusion, subjects who present a higher subjective risk value are the ones aware of their objective risk value (50\%), the most educated individuals and the elderly, that is, the more informed and more experienced subjects. The way in which people approach and evaluate risks is, in fact, influenced by other people (Joffe, 2003), namely closest people, who have or may have the disease. Accordingly, it can be stated that people's emotional reactions to risk may often depend on the vividness with which negative consequences can be imagined or experienced (Weber, 2006).

\section{Practice Implications}

Knowledge of risk perception in people at-risk for a hereditary neurodegenerative disease such as FAP allows psychologists to offer appropriate counselling to patients about the potential distress they might feel. Moreover, and as Pelletier and Dorval (2004) have also found, education and counselling in the context of genetic testing may clarify misconceptions about hereditary diseases and help counselees and their family members to make informed decisions about whether to undergo PST or not. 
Human Studies and Informed Consent

All procedures followed were in accordance with the ethical standards of the responsible committee on human experimentation (institutional and national) and with the Helsinki Declaration of 1975, as revised in 2000 (5). Informed consent was obtained from all patients for their inclusion in the study.

\section{References}

Al-Rawad, M., \& Al Khattab, A. (2015). Risk perception in a developing country: The case of Jordan. International Business Research, 8(1), 81-96. http:// dx.doi.org/10.5539/ibr.v8n1p81

Brewer, N. T., Chapman, G. B., Gibbons, F. X., Gerrard, M., McCaul, K. D., \& Weinstein, N. D. (2007). Metaanalysis of the relationship between risk perception and health behavior: The example of vaccination. Health Psychology, 26(2), 136-145. http:// dx.doi.org/10.1037/0278-6133.26.2.136

Cantor, N., \& Norem, J. K. (1989). Defensive pessimism and stress coping. Social Cognition, 7, 92-112. http:// dx.doi.org/10.1521/soco.1989.7.2.92

Coelho, T., Maia, L. F., Martins da Silva, A., Waddington, M., PlantéBordeneuve, V., Lozeron, P., ... Grogan, D. R. (2012). Tafamidis for transthyretin familial amyloid polyneuropathy: A randomized, controlled trial. Neurology, 79, 785-792. http://dx.doi.org/10.1212/ WNL.0b013e3182661eb1

Coutinho, P. (1976). Aspectos neurológicos da PAF. Boletim do Hospital, 1, 27-34.

Cox, S. M., \& McKellin, W. (1999). 'There's this thing in our family': Predictive testing and the construction of risk for Huntington Disease. Sociology of Health EF Illness, 21(5), 622-646. http:// dx.doi.org/10.1111/1467-9566.00176

Darker, C., \& Phillips, A. (2016). Risk perception. In M. Gellman
\& R. Turner (Eds.), Encyclopedia of Behavioral Medicine (pp. 1-3). New York: Springer-Verlag. http:// dx.doi.org/10.1007/978-1-4614-6439-6_866-2

Etchegary, H. (2011). 'I put it on the back burner most days': Living with chronic risk. Health, 15(6), 633-649. http:// dx.doi.org/10.1177/1363459310364162

Evers-Kiebooms, G., \& Decruyenaere, M. (1998). Predictive testing for Huntington's disease: A challenge for persons at risk and for professionals. Patient Education and Counseling, 35, 15-26. http://dx.doi.org/10.1016/ S0738-3991(98)00086-X

Evers-Kiebooms, G., \& Fryns, J. P. (1999). Conseil génétique dans les maladies neurodégénératives: Approche multidisciplinaire dans le diagnostic prédictif. In A. Brice \& D. F. Schorderet (Eds.), Neurogénétique: Affections hérédodégénératives, Collection Traité de neurologie (pp. 13-22). Paris: Doin.

Evers-Kiebooms, G., Welkenhuysen, M., Claes, E., Decruyenaere, M., \& Denayer, L. (2000). The psychological complexity of predictive testing for late onset neurogenetic diseases and hereditary cancers: implications for multidisciplinary counselling and for genetic education. Social Science \& Medicine, 51 (6), 831-841. http://dx.doi.org/10.1016/ S0277-9536(00)00064-2

Folstein, S. E., Franz, M. L., Jensen, B. A., Chase, G. A., \& Folstein, M. F. (1983). Conduct disorder and affective disorder among offspring of patients with Huntington's disease. Psychological Medicine, 13(1), 45-52. http:// dx.doi.org/10.1017/S0033291700050054

Hoffmann, T. C., \& Del Mar, C. (2015). Patients' expectations of the benefits and harms of treatments, screening, and tests: A systematic review. JAMA Internal Medicine, 175(2), 274-286. http:// dx.doi.org/10.1001/ jamainternmed.2014.6016 
Ângela Leite, Maria Alzira Pimenta Dinis, Jorge Sequeiros, Et al.

Inouye, J. (2014). Risk perception: Theories, strategies, and next steps. Wellington: Campbell Institute.

Jamieson, C. E. (2001). Genetic testing for late onset diseases: Current research practices and analysis of policy development. Ottawa: Health Canada Applied Research and Analysis Directorate.

Joffe, H. (2003). Risk: From perception to social representation. British Journal of Social Psychology, 42(1), 55-73. http:// dx.doi.org/10.1348/014466603763276126

Lippman-Hand, A., \& Fraser, F. C. (1979). Genetic counselling - The postcounselling period: I. Parents' perceptions of uncertainty. American Journal Medicine Genetics, 4(1), 51-71. http:// dx.doi.org/10.1002/ajmg.1320040108

Patenaude, A. F., Guttmacher, A. E., \& Collins, F. S. (2002). Genetic testing and psychology: New rules, new responsabilities. American Psychologist, 57(4), 271-282. http:// dx.doi.org/10.1037/0003-066X.57.4.271

Pelletier, S., \& Dorval, M. (2004). Predictive genetic testing raises new professional challenges for psychologists. Canadian Psychology, 45(1), 16-30. http:// dx.doi.org/10.1037/h0086968

Petersen, A. (2001). Biofantasies: Genetics and medicine in the print media. Social Science and Medicine, 52(8), 1255-1268. http://dx.doi.org/10.1016/ S0277-9536(00)00229-X

Quaid, K. A., Sims, S. L., Swenson, M. M., Harrison, J. M., Moskowitz, C., Stepanov, N., ... Westphal, B. J. (2008). Living at risk: Concealing risk and preserving hope in Huntington disease. Journal Genetic Counseling, 17(1), 117-128. http:// dx.doi.org/10.1007/s10897-007-9133-0

Sequeiros, J. (1996). Aconselhamento genético e teste preditivo na doença de MachadoJoseph. In J. Sequeiros (Ed.), O Teste Preditivo da doença de Machado-Joseph (pp. 33-48). Porto: UnIGENe, IBMC.

Siaki, L. A., Loescher, L. J., \& Trego, L. L. (2013). Synthesis strategy: Building a culturally sensitive mid- range theory of risk perception using literary, quantitative, and qualitative methods. Journal of Advanced Nursing, 69(3), 726-737. http://dx.doi.org/10.1111/ j.1365-2648.2012.06096

Sjöberg, L. (2004). Principles of risk perception applied to gene technology. To overcome the resistance to applications of biotechnology, research on risk perception must take a closer look at the public's reasons for rejecting this technology. EMBO Reports, 5(S1), S47-S51. http:// dx.doi.org/10.1038/sj.embor.7400258

Sjöberg, L. (2012). Risk perception and societal response. In Handbook of risk theory (pp. 661-675). Netherlands: Springer.

Sjöberg, L., Moen, B. -E., \& Rundmo, T. (2004). Explaining risk perception. An evaluation of the psychometric paradigm in risk perception research. Trondheim: Rotunde Publikasjoner.

Slovic, P. (1987). Perception of risk. Science, 236(4799), 280-285. http:// dx.doi.org/10.2307/1698637

Slovic, P., \& Elke, W. (2002, April). Perception of risk posed by extreme events. Paper presented at the Conference Risk Management Strategies in an Uncertain World, New York. Retrieved from https:/www.ldeo.columbia.edu/chrr/ documents/meetings/roundtable/pdf/round table_exec_final.pdf

Slovic, P., \& Peters, E. (2006). Risk perception and affect. Current Directions in Psychological Science, 15, 6322-325. http://dx.doi.org/10.1111/ j.1467-8721.2006.00461

Taylor, S. D. (2003). Predictive testing for an individual at $25 \%$ risk for Huntington's disease: Present conundrums, future challenges. Journal of Futures Studies, 7(4), 27-36.

Ulleberg, P., \& Rundmo, T. (1996, September). Risk perception, affectivity and health. Presented at the 10th Conference of European Health Psychology, Dublin, Ireland. 
Weber, E. U. (2006). Evidence-based and description-based perceptions of long term risk: Why global warming does not scare us (yet). Climatic Change, $\quad 77(1-2), \quad$ 103-120. http:// dx.doi.org/10.1007/s10584-006-9060-3

Wexler, N. S. (1979). Genetic "russian roulette": The experience of being "at risk" for Huntington's disease. In S. Kessler (Ed.), Genetic counselling: Psychological dimensions (pp. 199-220). London: Academic Press.

\section{Notes}

* Research article. 